\title{
Improvement of Teacher's Performance through Development of Decision Making, Integrity, and Organizational Climate Using Sequential Explanatory Analysis
}

\author{
Wijiyono*, Soewarto Hardhienata, Rita Retnowati \\ Postgraduate Program, Pakuan University Bogor, Indonesia
}

*Corresponding Author: Wijiyono, Postgraduate Program, Pakuan University Bogor, Indonesia

\begin{abstract}
The purpose of this study was to find efforts to improve teacher performance by knowing the strength of variables thought to be related to teacher performance, namely decision making, organizational integrity, and climate individually or together with teacher performance. The population was taken from private Madrasah Tsanawiyah teachers in Tangerang Regency with a sample of 251 teachers made in proportional random sampling. Besides correlation analysis, Scientific Identification Theory of Operation Research in Education Management (SITOREM) is used to rank the hierarchy of necessity. Research results show that; (1) there is a positive relationship between decision making and teacher performance, with a coefficient correlation of $48.8 \%$, (2) there is a positive relationship between integrity and teacher performance, with a coefficient correlation of $51.9 \%$, (3) there is a positive relationship between organizational climate with teacher performance with a coefficient correlation of $37.8 \%$ and there is a positive relationship of decision making (X1), integrity (X2) and organizational climate (X3) together with teacher performance with a coefficient correlation of $85.3 \%$. Besides other factors are positively related to the increase in teacher performance, which is $27.2 \%$. The results of the qualitative research also show that decision making, organizational integrity, and climate can improve teacher performance.
\end{abstract}

Keywords: Decision Making, Integrity, Organizational Climate, Teacher Performance

\section{INTRODUCTION}

Teachers are the most critical part of improving the quality of education. As an educator, the teacher is an educational leader who is very decisive in the learning process in the classroom, and the leadership role will be reflected in how the teacher performs his duties indicating that teacher performance is a very decisive factor for education quality which has implications for the quality of output educational. Therefore, the development and improvement of teacher performance need to be done in an organizational framework to encourage the development process and to increase the teacher's performance. The development and growth of individual teacher performance must be an elaboration of the organization's strategic plan so that the direction and objectives and work targets to be achieved and developed are part of the integrated goals of the organization (Fullan,2014).

Teacher performance is an essential component in improving the quality of education, which will impact on the quality of human resources. Teachers play a vital role in increasing the intelligence of students because the teacher has a duty as a direct implementer in the education process. Given the importance of the part of teacher performance in the quality of education and human resources in Indonesia, it is natural to assume that the reality of the achievement of the Human Development Index in Indonesia is not in line with expectations, as a result of teacher performance. The report of United Nations Development Program (UNDP) in the last two years (2015-2016) on the Indonesian Development Index (HDI) or Human Development Index (HDI) placed Indonesia in the middle category out of 188 participants surveyed (UNDP, 2016). Not yet optimal teacher performance is seen from the acquisition of the results of the junior/madrasa teacher's competency test nationally, and the average value reaches 65.33 of the 100 scales (Ministry of education, 2016). The results of teacher competence are a reflection of the not yet optimal improvement in teacher performance which of course will be related to the achievement of educational goals.

Based on the description above, it shows that teacher performance is essential for the organization so that it can produce graduates and quality. However, the results of the preliminary survey show 
empirical facts that the performance of private Madrasah teachers in Tangerang Regency is not optimal where there is a gap between empirical facts and expected so that it can cause problems in improving the quality of education. Therefore, it is necessary to research teacher performance and other variables that are considered to be related to teacher performance, so that there are additional useful insights and knowledge in improving teacher quality and education quality. Based on the background of the problem, identification of problems, limitation of the problem, the formulation of the problem precisely as follows:

- Is there a relationship between decision making and teacher performance?

- Is there a relationship between integrity and teacher performance?

- Is there a relationship between organizational climate and teacher performance?

- Is there a relationship between decision making, integrity, organizational climate, together with teacher performance?

\section{LITERATURE REVIEW}

According to Achim (2014), performance is a condition as a whole over the organization for a certain period, as a result, related to the operational activities of the organization in utilizing the resources it has. Furthermore, according to Spyer (2010), suggest three factors related to performance, namely (1) individual attributes which include abilities and experiences; (2) organizational support such as resources and technology; (3) effort to work (an effort to the job).

About teacher's performance, Kivimi et al. (2013) classify teacher performance into three factors, namely (1) work conditions; (2) teaching load; (3) personal interaction. Whereas according to Adeyemi (2008), teacher performance is an action to achieve or execute a task that has been given in the eight dimensions, namely (1) lesson preparation; (2) lesson presentation; (3) reports of teaching activities ; (4) implementation of teaching activities (actual teaching); (5) teacher's commitment ; (6) leadership effectiveness; (7) motivation, and (8) school discipline. Smith and Pellegrini (2000) revealed that the dimensions of teacher performance are three, namely (1) lesson preparation, planning and evaluation which includes teaching methods, homework assignments; (2) classroom and behavior management includes monitoring in student engagement; (3) improvement of student learning includes the level of accuracy, thinking ability and feedback.

Based on the theories and explained above, it can be synthesized that teacher performance is the result that has been achieved by the teacher in doing his work, contributing to his organization, carried out with full responsibility, both quantitative and qualitative in a certain period of time, to achieve organizational goals, with indicators; (1) the results of planning the preparation of learning activities; (2) results of the implementation of learning activities; (3) results of evaluation of learning activities; (4) reports of learning activities.

The concept of decision making according to Hidayati (2016) is a process that includes a statement of purpose, defining a problem, determining a hypothesis, collecting data, testing hypotheses and clarity of results. Factors related to decision making are as follows: (1) decision; (2) internal organizational characteristics; (3) external environmental characteristics; (4) characteristics of the management team. Gibson et al. (2012) argue that decision making is related to choosing an action when facing a situation involving several alternatives, comparing between alternatives, using selected alternatives to solve problems and evaluating the results in the organization. The stages of decision making go through five stages, namely: (1) establishing goals; (2) identifying alternatives; (3) evaluating alternatives; (4) choosing an alternative; (5) implementing the decision.

According to Rodliyah (2013), the three dimensions of decision making in schools are (1) dimensions of content, (2) dimensions of processes, (3) dimensions of involvement. The content dimension includes learning programs, human resources, funds or budgets, and organizational relationships. The process dimension includes identifying problems, defining problems, formulating and weighing alternatives, implementing decisions and evaluating decisions. The dimensions of engagement relate to participating individuals and the level of individual participation. The level of involvement is intended in terms of making decisions, proposing alternatives, helping formulating alternatives, providing information for compilation, and having no involvement at all. Shahid Amena and Shahid 
M. Azar (2013: 66), stated that integrity is an individual who shows strong morality and has ethical principles in his environment. Furthermore, it reveals that integrity is related to three factors, namely: (1) value coherence; (2) consistency; (3) trust. In contrast to the theory put forward Djumarna and Lies Hendrawan (2016: 117) argues that integrity is the attitude of consistent actions, values, methods, steps, expectations, and results. Then say that integrity has three dimensions as follows: (1) truth; (2) responsibility; (3) honesty. In contrast to the theory put forward by Stefan and Michaela (2006: 28) confirming factors related to integrity are (1) agreeableness; (2) emotional stability (emotional stability); (3) conscientiousness.

Duggar (2014) explains integrity is seen from one's character in the following areas; (1) considerate; (2) compassion; (3) transparent ; (4) honesty ; (5) ethics. Meanwhile, Thomas (2001) says that integrity is a collection of values and norms which is in line with the opinion of Hubertts and Vanden (2003) where integrity is defined as actions that are by moral values and norms. This is supported by the theory put forward by Othman (2014) who argues that integrity is a consideration of individual moral values for actions taken.

Werang (2014), reveals that organizational climate is a norm, value, expectation, policy, and procedure that exists within the organization, which influences a person's motivation, commitment, and satisfaction with their work. Furthermore, it reveals four dimensions related to organizational climate, namely (1) norms; (2) value; (3) beliefs; (4) culture.

Based on the description of the framework, a temporary conclusion is made that needs proof in the form of a hypothesis. Of the four variables studied, namely decision making, integrity, organizational climate, and teacher performance, the assumption was arranged as follows:

- There is a positive relationship between decision making and teacher performance in private Madrasah Tsanawiyah (Islamic Junior High School).

- There is a positive relationship between integrity and teacher performance in private Madrasah Tsanawiyah (Islamic Junior High School).

- There is a positive relationship between organizational climate and teacher performance in private Madrasah Tsanawiyah (Islamic Junior High School).

- There is a positive relationship between decision making, integrity, and organizational climate together with teacher performance in private Madrasah Tsanawiyah (Islamic Junior High School).

\section{METHODOLOGY}

Research sites were in Private Islamic Primary Schools in the Tangerang Regency area. The time of the study was conducted from March 2018 to August 2018. The study used a mix method design with sequential explanatory. The population of this research was 669 permanent teachers in private Madrasah in the Tangerang Regency, Indonesia. The research sample was calculated using a technique of proportional random sampling with a sample size of 251 teachers.

The technique data analysis used in this study is descriptive and inferential data analysis techniques. Descriptive data analysis techniques describe what it is about variables, symptom or condition are not intended to test hypotheses. The inferential analysis is used to test hypotheses using regression analysis while the analysis requirements test used the estimated standard error of normality test, Homogeneity test, check the significance of the regression and equation linearity. Finally, the Scientific Identification Theory of Operation Research in Education Management (SITOREM) is applied to rank the critical steps for improvement.

\section{RESULTS AND DiSCUSSION}

\subsection{The Relationship Between Decision Making and the Performance of Private Madrasah Teachers in Tangerang Regency}

The results of the study showed that there was a significant relationship between decision making and teacher performance. Based on the results of the study with hypothesis testing it is known that the correlation coefficient between decision making and teacher performance $\mathrm{r}_{\mathrm{yl}}=0.488$ with the category of having a strong relationship. The probability value is $0.000<0.005 \mathrm{so}_{\mathrm{o}}$ is rejected, leading to the 
Improvement of Teacher's Performance through Development of Decision Making, Integrity, and Organizational Climate Using Sequential Explanatory Analysis

conclusion that the correlation coefficient is significant. Any increase in the score of decision making will improve performance.

Table1. Linearity test and coefficient of correlation of Decision Making $\left(X_{1}\right)$ to Teacher Performance $(Y)$

\begin{tabular}{|c|c|c|c|c|c|}
\hline Observation & $\mathbf{R}$ & $\mathbf{R}^{2}$ & $\mathbf{F}_{\text {-test }}$ & $\mathbf{F}_{\text {-table }} \alpha$ & \multirow{2}{*}{ Conclusion } \\
\cline { 1 - 4 } $\mathbf{N}$ & $\mathbf{R}_{\mathbf{x} 1}$ & $\mathrm{r}^{2}{ }_{\mathbf{x} 1}$ & $\mathbf{F}_{\mathbf{x} 1}$ & 0.05 & \\
\hline 251 & 0.488 & 0.237 & 47.82 & 3.879 & Significant \\
\cline { 1 - 3 }
\end{tabular}

This relationship is strengthened by the partial correlation coefficient between decision making and performance and integrity as variable controller so that the correlation coefficient $\mathrm{ry}_{12}$ is obtained= 0.475 . The data means that the decision-making relationship with performance is very significant even though the variables of organizational integrity and climate are controlled. Findings from quantitative results indicate that the coefficient of determination between decision making and performance is $\mathrm{ry}_{12}=0.237$. This means that $23.7 \%$ of performance is a result of the contribution of decision-making variables, while $76.3 \%$ is contributed by other variables that have a relationship with improving teacher performance. This situation is corroborated by Olcum (2015), which states that decision making is a process that can be seen as a whole dynamic action, which begins with identifying the problem. The opportunity to be involved in decision making will motivate and encourage subordinates to be enthusiastic and enthusiastic in the learning process and classroom management and provide job satisfaction as educators. This enthusiasm, enthusiasm and job satisfaction will stimulate performance improvement. The teacher will do his work consciously, increase the ability to plan learning activities, (lesson preparation), carry out teaching (actual teaching), conduct evaluation of education (teaching evaluation), and be able to complete the report of teaching activity, so that performance teacher increases. (Rajiani,2013).

The quantitative data above is reinforced by data from qualitative research observations which have the conclusion that decision making qualitatively in the field has the same tendency as decision making in quantitative research.

\subsection{The Relationship Between Integrity and the Performance of Private Madrasah Teachers in Tangerang Regency}

The results of the study showed that there was a significant relationship between integrity and teacher performance. Based on the results of the study with hypothesis testing it is known that the correlation coefficient between integrity and Teacher Performance $r_{y 1}=0.516$ with the category having a strong relationship. The probability value is $0.000<0.005$ so $\mathrm{H}_{\mathrm{o}}$ is rejected. Thus, it is concluded that the correlation coefficient is significant. Any increase in the score of integrity will improve performance.

Table2. Linearity test and coefficient of correlation of Integrity $\left(X_{2}\right)$ to Teacher Performance $(Y)$

\begin{tabular}{|c|c|c|c|c|c|}
\hline Observation & $\mathbf{R}$ & $\mathbf{R}^{\mathbf{2}}$ & $\mathbf{F}_{\text {-test }}$ & $\mathbf{F}_{\text {-table }} \alpha$ & \multirow{2}{*}{ Conclusion } \\
\hline $\mathbf{N}$ & $\mathbf{R}_{\mathbf{x} 2}$ & $\mathbf{r}_{\mathbf{x} 2}^{2}$ & $\mathbf{F}_{\mathbf{x} 2}$ & 0.05 & \\
\hline 251 & 0.519 & 0.269 & 92.108 & 3.879 & Significant \\
\hline
\end{tabular}

Findings from the results of quantitative research indicate that the coefficient of determination between integrity and performance is $\mathrm{ry}_{22}=0.269$. This means that $26.9 \%$ of performance is the result of the contribution of decision-making variables, while $73.1 \%$ is contributed by other variables that have a relationship with performance improvement.

The findings in this study indicate that integrity is the most decisive variable concerning teacher performance compared to decision-making variables and organizational climate. The relationship of integrity $\left(\mathrm{X}_{2}\right)$ with performance $(\mathrm{Y})$ is higher than decision making $\left(\mathrm{X}_{1}\right)$ and organizational climate $\left(X_{3}\right)$. This means that if the teacher has a high quality of integrity, it can improve performance. This is in line with the theory put forward by Lilian (2011), stating that integrity is the superiority of individuals who make a person live healthier, no burden, and live his life far from pretense, and remain consistent in condition any despite emphasis, as well as sticking to the values that it adheres to.

The quantitative data above is reinforced by data from qualitative research observations which have the conclusion that integrity qualitatively in the field has the same tendency as integrity in quantitative research. 
Improvement of Teacher's Performance through Development of Decision Making, Integrity, and Organizational Climate Using Sequential Explanatory Analysis

\subsection{Relationship Between Organizational Climate and Private Madrasah Teachers' Performance in Tangerang Regency}

The results of the study showed that there was a significant relationship between organizational climate and teacher performance. Based on the results of the survey with hypothesis testing it is known that the correlation coefficient between Integrity and Teacher Performance $r_{y 1}=0.209$ with the category having a strong relationship. The probability value is $0.000<0.005$ so $\mathrm{H}_{\mathrm{o}}$ is rejected, it can be concluded that the correlation coefficient is significant. Any increase in the score of decision making will improve performance.

Table3. Linearity test and coefficient of correlation of Organizational Climate $\left(X_{3}\right)$ to Teacher Performance $(Y)$

\begin{tabular}{|c|c|c|c|c|c|}
\hline Observation & $\mathbf{R}$ & $\mathbf{R}^{2}$ & $\mathbf{F}_{\text {-test }}$ & $\mathbf{F}_{\text {-table }} \alpha$ & \multirow{2}{*}{ Conclusion } \\
\hline $\mathbf{N}$ & $\mathbf{R}_{\mathbf{x} 3}$ & $\mathbf{r}_{\mathbf{x} 3}^{2}$ & $\mathbf{F}_{\mathbf{x} 3}$ & 0.05 & \\
\hline 251 & 0.378 & 0.1430 & 41.546 & 3.879 & Significant \\
\cline { 1 - 1 }
\end{tabular}

They are then based on the calculation of the partial correlation test with the controller of the integrity variable the value of $\mathrm{ry}_{32}=0.472$. The data implies that organizational climate relations with performance are significant even though the decision-making and integrity variables are controlled. Findings from quantitative results indicate that the coefficient of determination between decision making and performance is $\mathrm{ry}_{32}=0.143$. This means that $14.3 \%$ of performance is the result of the working of decision-making variables, while $85.7 \%$ is contributed by other variables that have a relationship with improving teacher performance.

The findings obtained in the field indicate that each teacher needs fulfillment, as a source of motivation to increase his teaching spirit. The conducive atmosphere in his work climate will stimulate the teacher in carrying out his duties. The comfortable feeling that is felt by individuals will encourage an increase in interpersonal interactions, accompanied by the support of superiors to their subordinates so that an atmosphere full of kinship will be formed. Encouragement to be fair, open in solving problems will have an impact on subordinates so that subordinates feel recognized individual rights. As a result, individuals will be encouraged to contribute, work more productively to achieve organizational goals, so that teacher performance increases. This is following the theory put forward by Ambrose (2008), revealing that the organizational climate is a norm, values, expectations, policies, and procedures that exist within the organization, which influence a person's motivation, commitment, and satisfaction with his work.

\subsection{The Relationship between Organizational Decision Making, Integrity and Climate with Private Madrasah Teacher Performance in Tangerang Regency}

The results of hypothesis testing indicate that there is a functional relationship between decision making, organizational integrity and climate together with performance, regression equation $\hat{\mathrm{Y}}=36.68$ $+0.35 \mathrm{X}_{1}+0.38 \mathrm{X}_{2}+0.15 \mathrm{X}_{3}$, with $\mathrm{F}_{\text {count }}=72.569$, while $\mathrm{F}_{\text {table }}(\alpha=0.05=2.411)$ and $\mathrm{F}_{\text {table }}(\alpha=0.01=$ 2.8618), which means that regression significance is very significant. The resulting multiple correlation coefficient of correlation $=0.853$, which indicates that an increase in the score of decision making, organizational integrity and climate together will improve teacher performance.

The findings of this study are the coefficient of determination between decision making, organizational integrity, and climate together with performance is $=0.721$. This means that $72.1 \%$ of performance is the result of the work of decision-making variables, organizational integrity, and climate together, while $27.9 \%$ is contributed by other variables that have a relationship with improving teacher performance.

The relationship among variables is then presented by scientific identification theory or operation research in education management (SITOREM) as postulated by Hardhienata (2017).

The trend that can be seen from the results of this study is the correlation between decision making, organizational integrity and climate with teacher performance, namely $r_{y 1}=0.488$. When compared with the correlation between integrity and teacher performance, $r_{y 2}=0.519$ and the relationship between organizational climate and performance teacher, i.e., $r_{y 3}=0.378$, it can be seen that integrity is the highest variable contributing to performance. The findings obtained in this quantitative research phase show that $72.8 \%$ of teacher performance is the result of the decision making, integrity, and 
organizational climate together while $27.2 \%$ of teacher performance is contributed by other variables that have a relationship with improving teacher performance.
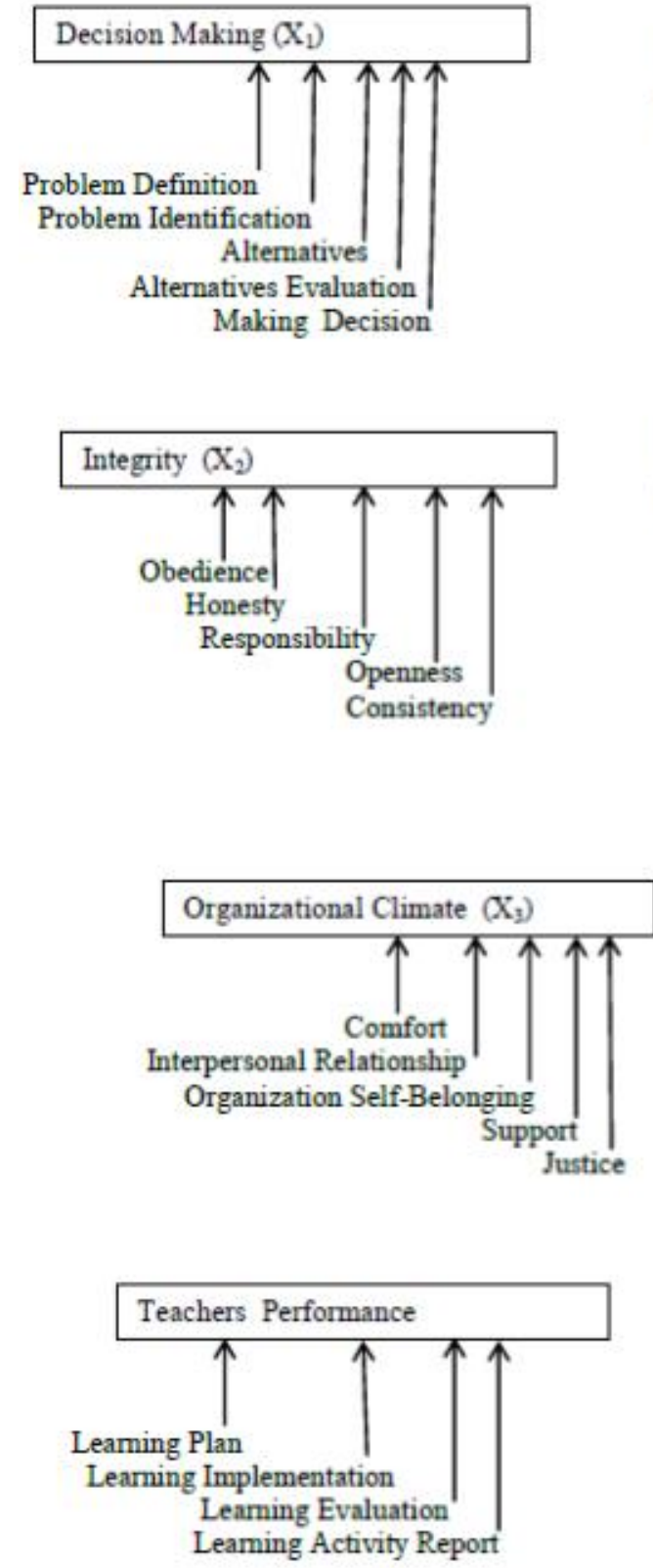

$$
R_{\mathrm{y} 1}=0.488
$$

\section{WEIGHING AND INDICATOR SCORES}

1. Problem Definition $(30 \%)(4.03)$

2. Alternatives (25\%)(3.83)

3. Problem Identification $(20 \%)(3.59)$

4. Alternatives Evaluation (15\%)(3.84)

5. Making Decision $(10 \%)(3.54)$

$$
R_{y_{2}}=0.509
$$

\section{WEIGHING AND INDICATOR SCORES}

1. Honesty $(30 \%)(3.67)$

2. Obedience $(25 \%)(4.04)$

3. Responsibility $(20 \%)(3.48)$

4. Openness (15\%) (3.16)

5. Consistency $(10 \%)(3.30)$
$R_{y 3}=0.378$

\section{WEIGHING AND INDICATOR SCORES}

1. Interpersonal Relationship $(30 \%)(4.01)$

2. Organization Self-Belonging $(25 \%)(3.30)$

3. Comfort $(20 \%)(3.61)$

4. Justice $(15 \%)(3.44)$

5. Support $(10 \%)(3.24)$

Figure1. SITOREM

\section{CONCLuSion}

The research concludes that there is a very significant positive correlation between the decision by the correlation coefficient $\left(\mathrm{ry}_{1}\right)=0.488$ and the coefficient of determination $\left.\left(\mathrm{r}_{2}\right)=0.237\right)$, which means $23.7 \%$ increase in the contribution of teacher performance is the result of retrieval decision. There is a very significant positive relationship between integrity and teacher performance with a correlation coefficient $\left(\mathrm{ry}_{2}\right)=0.519$ and a coefficient of determination $\left(\mathrm{r}_{2}\right)=0.269$ which means that $26.9 \%$ increase in teacher performance is a result of integrity contribution. There is a very significant positive relationship between organizational climate and teacher performance with a correlation coefficient $\left(r_{\mathrm{y} 3}\right)=0.378$ and a coefficient of determination $\left(r_{2}\right)=0.143$. This is mean that $14.29 \%$ increase in teacher performance is the result of organizational climate and the last a very significant positive relationship between decision making, organizational integrity and climate together with teacher performance, with $\mathrm{r}$ correlation coefficient $\mathrm{y}_{123}=0.853$ and the coefficient of determination $\left(\mathrm{ry}_{123}\right)=$ 0.728 , meaning that $72.8 \%$ increase in production is the result of contributions between organizational decisions, integrity and climate altogether. 
Improvement of Teacher's Performance through Development of Decision Making, Integrity, and Organizational Climate Using Sequential Explanatory Analysis

\section{REFERENCES}

[1] Achim, Monica-Violeta, and N. S. Borlea. "Environmental performances-way to boost up financial performances of companies." Environmental engineering and management journal 13, no. 4 (2014): 991-1005.

[2] Adeyemi.T,O.(2008) Organizational Climate and Teacher's Job Performance in Primary Schools In Ondo state, Nigeria: An Analytical Survey. Asian Journal of Information Technology.Vol.7 (4).pp.138-140.

[3] Ambrose, Maureen L., Anke Arnaud, and Marshall Schminke. "Individual moral development and ethical climate: The influence of person-organization fit on job attitudes." Journal of Business Ethics 77, no. 3 (2008): 323-333.

[4] Al-Sharafi, Hamed, and Ismi Rajiani. "Leadership practices and talent turnover: Study on Yemeni organizations." Business and Management Research 2, no. 3 (2013): 60-67.

[5] Duggar Jan W. (2014).The Role of Integrity in Individual and effective Corporate Leadership.Journal of Academic and Business Ethics.Vol.5 (20).pp.1-7.

[6] Fullan, Michael. Teacher development and educational change. Routledge, 2014.

[7] Gibson,James L., John M. Ivancevich, James H. Donnely and Robert Konopaske J. (2008). Organisasi dan Manajemen, Perilaku, Struktur, Proses, (Terjemahan oleh Djuerban Wahid), Jakarta.Erlangga.

[8] Hardhienata, S. The development of scientific identification theory to conduct operation research in education management, IOP Conf. Series: Materials Science and Engineering 166 (2017) 012007 doi: 10.1088 / 1757 - 899X / 166 / I / 012007.

[9] Hidayati, Tetra, and Rahmawati Rahmawati. "The effect on the job satisfaction organization, performance of employees commitment, and service performance." KINERJA 13, no. 1 (2016): 1-12.

[10] Hubertts, L.W.J.L. E.W Kolthoff and H. Vanden Heuvel. (2003). The Ethics of Government and Business: What is Value Most, Paper Presented at The Conference of the European Group of Public Administration. Oeras Portugal.

[11] Kivimi, Florencia K., Raphael Mwiti Gikunda, James Obara, and Joash Kibett. (2013). Influence of Selected Motivational Factors on The Performance of Secondary School Agriculture Teacher's in Imenti South District Kenya. International Journal of Education and Research.vol.1 No. 6. pp.1-16.

[12] Lillian, G. O., P. Mathooko, and N. Sitati. "The Effects of Performance Appraisal System on Civil Servants Job Performance and Motivation in Kenya: A Case Study Of Ministry of State For Public Service." In Proceedings of Kabarak University 1st annual international research conference, p. 370. (2011).

[13] Olcum, Dincer, and Osman Titrek. "The effect of school administrators' decision-making styles on teacher job satisfaction." Procedia-Social and Behavioral Sciences 197 (2015): 1936-1946.

[14] Othman. (2014). Influence of Job Satisfaction and Codes of Ethics on Integrity Among Police Officers. Procedia Social and Behavioral Sciences.Vol.145. pp.266-276.

[15] Rodliyah, S.T. Partisipasi Masyarakat dalam Pengambilan Keputusan dan Perencanaan di Sekolah. Yogyakarta: Pustaka Pelajar, (2013).

[16] Smith, P. K., \& Pellegrini, A. D. (Eds.). (2000). Psychology of Education: Schools, teachers and parents (Vol. 1). Taylor \& Francis.

[17] Soyer, Fikret, Yusuf Can, and Kürşat Akbulut. "Examining the relationship between organizational commitment and job satisfaction levels of football coaches." Journal of Human Sciences 7, no. 2 (2010): 515-526.

[18] Thomas, Rosamund M. Public Trust, Integrity and Privatization. Public Integrity. Vol.3.Issue.3.pp.234261. (2001).

[19] Werang, Basilius Redan, and Lukas Lena. "Relationship between Principal's Leadership, School Organizational Climate, and Teachers' Job Performance at State Senior High Schools in Merauke Regency-Papua-Indonesia." International Journal of Education and Research 2, no. 6 (2014): 635-640.

Citation: Wijiyono, et.al. “ Improvement of Teacher's Performance through Development of Decision Making, Integrity, and Organizational Climate Using Sequential Explanatory Analysis " International Journal of Managerial Studies and Research (IJMSR), vol 7, no. 4, 2019, pp. 40-46. doi: http://dx.doi.org/10.20431/ 2349-0349.0704006.

Copyright: (C) 2019 Authors. This is an open-access article distributed under the terms of the Creative Commons Attribution License, which permits unrestricted use, distribution, and reproduction in any medium, provided the original author and source are credited. 